\title{
Digital transformation and economic cooperation: The case of Western Balkan countries*
}

\author{
Tanja Broz ${ }^{1}$, Goran Buturac ${ }^{2}$, Miloš Parežanin ${ }^{3}$
}

\begin{abstract}
Digital transformation is increasingly affecting many aspects of the world economy. It is boosting economic growth, has an impact on foreign direct investments and increases international trade. Hence, the aim of the paper is to analyse digital transformation in relation with the economic cooperation between Western Balkan economies. In order to do so, we construct two indicators: the harmonised index of economic cooperation among Western Balkan economies and the indicator of digital transformation convergence. The results indicate a rising trend of economic cooperation amongst Western Balkan countries, with cooperation dominated by foreign trade. Even though Western Balkan countries have experienced an increased digital transformation convergence, they are still lagging behind the EU in the use of digital technologies. Hence, placing more emphasis on digital transformation could potentially boost the region's GDP and thus economic cooperation among them.
\end{abstract}

Key words: digital transformation, regional economic cooperation, Western Balkan countries

JEL classification: F15, F21, O33

\footnotetext{
Received: 01-06-2019; accepted: 11-11-2020

1 Senior Research Associate, The Institute of Economics, Zagreb, Trg J. F. Kennedyja 7, 10000 Zagreb, Croatia. Phone: +38512362 233.E-mail: tbroz@eizg.hr.

2 Senior Research Fellow in Permanent Position, The Institute of Economics, Zagreb, Trg J. F. Kennedyja 7, 10000 Zagreb, Croatia. Phone: +385 12362 297.E-mail: gbuturac@eizg.hr.

3 Teaching Assistant, University of Belgrade, Faculty of Organizational Sciences, Jove Ilića 154, Belgrade, Serbia.Phone: +381113950 919.E-mail:milos.parezanin@fon.bg.ac.rs.
} 


\section{Introduction}

Digital transformation has affected all the countries in the world. It has changed the way business is conducted, people's habits and it has increased the availability of products and services. ${ }^{4}$ At the same time the process of digitalisation is viewed as one of the drivers of economic development. It has macroeconomic, sectoral, and microeconomic effects, but it may also boost regional economic cooperation.

Western Balkan countries are still lagging behind more developed post-transition countries and they need a stronger push in order to catch up. Since existing research has indicated a positive relationship between digitalisation and GDP (e.g. Kabaklarli and Atasoy, 2019; Czernich et al., 2011; Roller and Waverman, 2001), one of the sources for a stronger development in the Western Balkans might be increased digitalisation. More precisely, an increased digital transformation across the Western Balkan region could increase their GDP growth and thus increase economic cooperation between the countries in the region (Minges, 2015; Duttaray et al., 2008; Barrell and Pain, 1996). ${ }^{5}$ Digital transformation should also improve the region's attractiveness and increase investments from both the EU's private sector and international financial institutions.

The goal of the paper is to analyse the digital transformation in relation with the economic cooperation between the Western Balkan economies. More precisely, we aim to analyse trends in digital convergence amongst Western Balkan economies, the dynamics of economic cooperation between them as well as to discuss the impacts of digital transformation on economic cooperation among the analysed countries. The main hypothesis of this research is that, along with the process of digital convergence between Western Balkan countries, there is a strengthening of economic cooperation between them. The research includes the following countries: Albania, Bosnia and Herzegovina, Croatia, Kosovo, Montenegro, North Macedonia and Serbia. The reference period of the research is from 2007 to 2017. In order to achieve this, two indicators were constructed and analysed: the harmonised index of economic cooperation among Western Balkan economies and the indicator of digital transformation convergence. In order to construct the harmonised index of economic cooperation, we use data on bilateral merchandise trade flows, foreign direct investments (FDI), and tourist arrivals among Western Balkan economies, while for the calculation regarding the digital transformation convergence indicator, we use various digitalisation variables.

$\overline{4}$ However, it is also affecting existing jobs, equality and resource efficiency.

5 Since GDP growth and economic cooperation are endogenous, there is also a reversed causality between them, meaning that increased economic cooperation also increases region's GDP (Liu et al., 2002; Hsiao and Hsiao, 2006; Gries and Redlin, 2012). 
Systematic empirical research on the digital convergence for Western Balkan countries, especially those relating digitalization to economic cooperation, was not previously conducted. The contribution of this paper to literature is to gain new scientific knowledge on the digital transformation process and its contribution to economic cooperation using the sample of the Western Balkans. Despite the limited geographic scope, motivation for contributing to literature stems from the significance of digitization for small open economies and its contribution to economic cooperation among countries.

The rest of the paper is organised as follows. The next section briefly surveys the literature on the effects of digital transformation on the economy, section 3 gives an overview of the methodology applied in the research, while section 4 analyses the results. In section 5, the focus is on the discussion on the results, while the last section gives conclusions of the paper.

\section{Literature review}

The effects of the digitalization process on various macroeconomic variables over the last 20 years stimulated a significant interest of researchers. Along with the development of digitalisation measurement methodology (Lehr et al., 2006; Katz and Koutroumpis, 2013; Kotarba, 2017), the effects of the digitization process on inflation (Yi and Choi, 2005), employment (Katz et al., 2010; Degryse, 2016; Aubert-Tarby et al., 2018; Gómez-Plana and Latorre, 2019), productivity (Majumdar et al., 2009; Dedrick et al., 2013), foreign direct investment (Choi, 2003) and service trade (Freund and Weinhold, 2004; Choi, 2010) have been investigated. Still, most of the research has been devoted to the impact of digitalisation on economic growth and broadband penetration as one of the most frequently used proxies for the digitalisation of the economy.

The impact of digitalisation on economic growth has been found to be mostly positive, but the impact varies depending on the degree of development of the analysed countries. Minges (2015) reviews several studies on the broadband internet connectivity and concludes that, regardless of the methodology applied, broadband internet has had a positive impact on the GDP. However, the size of the impact is different for countries of different levels of development: a 10 percent increase in fixed broadband penetration would increase the GDP per capita between 1.4 and 3.2 percent in developing economies and between 0.9 and 1.5 percent in developed economies. Czernich et al. (2011) analysed OECD countries and confirmed a statistically significant correlation between the broadband penetration and economic growth. Roller and Waverman (2001) examined how the telecommunication infrastructure in 21 OECD countries and 14 non-OEDC countries affected the economic growth. Their results suggest that investments in 
the infrastructure of telecommunication could have a higher impact on the growth in OECD countries than in less-developed non-OECD countries. Arvin and Pradhan (2014) also showed that there is a significant impact of broadband penetration on the economic growth in G20 countries, while on the other hand, in emerging economies there is a reverse causality and higher economic growth leads to a higher broadband penetration. The empirical work that was conducted using panel data for the ASEAN countries from 1998-2011 suggests that the broadband penetration has a significantly positive relationship with GDP growth (Ng et al., 2013). On the other hand, the impact of digital technologies on the economic growth in MENA countries is very limited and the impact depends on the decision makers (Ghosh, 2017). In sub-Saharan Africa, due to the lack of ICT skills, this impact is almost negligible (Haftu, 2019). As an important determinant of the rate of economic growth in sub-Saharan Africa occurs a mobile cellular phone expansion (Lee et al., 2012). Inferior results for less developed countries might be connected with the lower penetration of broadband internet and other forms of digitalisation in those countries. Most studies argue that a certain threshold of broadband penetration is needed for the effect of fixed broadband to be noticeable (Minges, 2015). In that context, Koutroumpis (2009) suggests that for a significant impact on the growth, a critical mass in broadband penetration is 30 percent. These nonlinear effects are present in Scandinavian countries, which enjoy higher returns from their increased broadband participation. Similarly, Gruber and Koutroumpis (2011) concluded that the impact of mobile telecommunications on the economic development is smaller for countries with a low mobile penetration, which is usually the case in low-income countries. The authors find that in low-income countries the mobile telecommunications contribution to the growth of GDP is 0.11 percent, while for high-income countries the contribution is 0.20 percent.

It is not only the broadband internet but also more broadly defined information and communications technology (ICT) that have a positive impact on the GDP. Yousefi (2011) concludes that ICT plays a major role in the growth of high and upper-middle income groups, but fails to contribute to the growth of the lowermiddle income group countries. The author concludes that, contrary to previous studies, such findings suggest that the level of investment in ICT is not the cause of slow growth in lower-middle income countries. Choi and Yi (2018) examine the effect of internet (the number of internet users per 100 persons) on the relationship between R\&D expenditure and economic growth using the dataset covering 105 countries over the period 1994-2014. They argue that the positive effect of the $\mathrm{R} \& \mathrm{D}$ expenditure on economic growth is further strengthened by the internet. More precisely, the interaction between $R \& D$ expenditures and the internet proves to be an important factor for explaining the growth of GDP.

Global economic downturn in 2008 affected also investments in ICT. Since investments in ICT are related to GDP growth, Castaldo et al. (2018) argue, based 
on the research of panel data of 23 OECD countries during 1996-2010, that in times of crisis decision makers should encourage investments in ICT. However, it is not only the time of crisis when researchers advocate public investments in ICT. Gruber et al. (2014) analysed costs and benefits from broadband adoption in the EU and argued that, since benefits outweighed the investment costs and since the private sector is often reluctant to invest in broadband infrastructure due to high initial costs and long payback periods, there is a rationale for the public sector to subsidize investments in the broadband infrastructure. Majumdar et al. (2009) suggested that the government support in encouraging the deployment of broadband technologies generates the potential for increased productivity for the deploying firms.

Even though research studies are mainly focused on the impact of ICT on GDP growth, some attention is devoted to the impact on employment, international trade and FDI. Kolko (2012) examined broadband expansion and local economic and employment growth in the US during 1999-2006 and compared areas with a higher and a lower growth in broadband availability. The findings indicate a positive relationship between broadband expansion and employment growth. However, the author argued that local residents do not necessarily profit from increases in employment induced by broadband expansion as areas with faster broadband expansion experienced no greater increases in employment relative to other areas. Crandall et al. (2007) estimated the effect of broadband penetration on output and employment using data for the 48 US states over the 2003-2005 period. They found that for every 1 percent increase in broadband penetration, employment was projected to increase by $0.2-0.3$ percent, while the strongest effect was found for manufacturing and services industries. However, not all studies showed the positive effects of digitalisation on employment. The thing is that digitalisation, besides creating tremendous opportunities, poses new challenges to employers and employees (De Groen et al., 2017). In that context, Degryse (2016) discusses the negative impact of digitalisation on the workforce. He says that the digital revolution seems to reveal large inequalities between the low-income and the top of the market workers who are able to enjoy and profit from digital instruments much more than low-income workers.

Regarding the impact of ICT on international trade, by using the unbalanced panel of 175 countries in the period 2000-2013, Gnangnon and Iyer (2018) show that increasing internet usage should improve countries' integration into the world trade in commercial services market. Bai (2019) argues that the increase in the adoption of the internet should boost country's exports, especially in export of ICT-enabled services. Similar results for the impact of ICT on international trade can be found in Lin (2015), Barbero and Rodriguez-Crespo (2018) and Rodríguez-Crespo and Martínez-Zarzoso (2019), while evidence of the impact of internet diffusion on FDI holdings can be found in Lee (2016). 
Besides the effects on the aggregate level, ICT also has a positive impact on the micro level. Grimes et al. (2012) found that broadband adoption boosted firm productivity by 7-10 percent. Majumdar et al. (2009) also found a positive statistically significant correlation between the level of broadband deployment and the productivity of firm deploying broadband technology. In a recent study, Haller and Lyons (2019) explored the relationship between DSL broadband services and the productivity of a firm. They used firm level data from nine subsectors within the services and distribution sectors and did not find significant productivity effects when all sectors were taken into account. On the other hand, they found statistically significant positive effects of DLS broadband services on the firm's total factor productivity in ICT and administrative and support services sub-sectors.

Research on digitalisation in Central, Eastern and South-Eastern European countries is relatively scarce. Digital cooperation in transition countries is mainly focused on exchanging information with the help of using ICT and overcoming the crossborder barriers (Arouja, 2015). Piatkowski (2006) analysed the potential of ICT for faster convergence of the income level between eight transition economies and the EU-15 and the US. Results show that ICT contributed to a faster GDP growth and managed to augment convergence of the Czech Republic, Hungary, Poland, and Slovenia with the EU-15. On the other hand, Romania, Russia, Slovakia and Bulgaria are still lagging behind. Since more developed European countries have significantly better digital infrastructure than European post-transition countries, they are providing the technology to post-transition countries. However, living standards and the laws of a particular country can be a huge barrier for the further development of digitalisation and cooperation (Zoroja, 2011).

Countries in the Western Balkan region are lagging behind the more developed European countries when it comes to digital transformation (Mondekar, 2017). Since there are, to the best of our knowledge, no studies dealing with digitalisation convergence of Western Balkan countries, especially those relating digitalisation to economic cooperation, the rest of the paper is devoted to analysing those issues.

\section{Methodology}

\subsection{Research instrument}

In order to analyse economic cooperation and digital transformation between Western Balkan countries, we rely on the secondary data acquired from different sources. For the analysis of the economic cooperation we use international databases Eurostat COMEXT, wiiw FDI Database, World Tourism Organisation, the Kosovo Agency for Statistics and World Bank World Development Indicators, while for the 
analysis of digital transformation we use International Telecommunication Union World Telecommunication/ICT Indicators (WT/ICT) database.

\subsection{Statistical methods}

In order to measure the extent of economic cooperation between the economies in the region, we use a harmonised index of economic cooperation. The calculation of the harmonized index is based on the methodology applied in the paper Broz et al. (2015). However, unlike their index, which measures the economic cooperation between Croatia and the economies in the region, we measure the bilateral cooperation between all the economies in the region. In our framework, economic cooperation includes regional foreign trade, FDI and tourism. By using these three fields of cooperation, we are able to analyse trends in economic cooperation between the economies in the region.

In order to construct the index of economic cooperation, it is first necessary to calculate cooperation indices for individual fields (foreign trade, FDI, and tourism), which are then incorporated into the harmonized index of economic cooperation, with the weight of each cooperation index proportional to its monetary share in total cooperation.

For the calculation of the cooperation index in the field of foreign trade, we use the values of exports from an individual economy in the region to the other economy in the region in a respective year. Then the exports from all economy pairs are added together to come up with the total regional trade in a respective year. A similar procedure is followed for other fields: for FDI we use the sum of all foreign direct inflows from one economy in the region to the other economy in the region, and for tourism we use the sum of all arrivals of tourists from one economy in the region to the other economy in the region. The calculation of the individual cooperation indices (CI) hence corresponds to the base index formula:

$$
C I_{t}=\frac{y_{t}}{\mathrm{y}_{b}} * 100, t=2007, \ldots, 2017
$$

where $y_{t}$ represents the monetary value of regional trade and FDI, as well as tourist arrivals in year $t$, while $y_{b}$ denotes the corresponding value in the base year (2007). The increase in the indices represents the increase in regional cooperation.

For the purpose of calculating the harmonized index of economic cooperation, which includes all fields, we need to construct weights for each specific field. Ideally, in order to construct weights, we should have monetary values for all the variables. However, since the data for earnings from regional tourists is not available, we had to estimate it from the total earnings from tourism using regional tourist arrivals. First, we calculated the share of regional tourists in all tourist 
arrivals, and then we multiplied this share with the total earnings from tourism for all economies, which gave us the estimate of regional earnings from tourism. ${ }^{6}$ After we had obtained all three monetary values, we were able to construct the weights of the individual categories of economic cooperation:

$$
w_{i t}=\frac{m_{i t}}{\sum_{i=1}^{3} m_{i t}}, i=1,2,3 ; t=2007, \ldots, 2017
$$

where $m_{i t}$ stands for the monetary values of regional trade, FDI, and tourism. The sum of all three weights is 1 .

The harmonised index of economic cooperation is then calculated as follows:

$$
H I E C_{t}=\sum_{i=1}^{3} C I_{i t} * w_{i t}, t=2007, \ldots, 2017
$$

In other words, we weighted the developments in the individual cooperation indices with their share in total regional economic cooperation. Again, the increase in the index represents the increase in the regional economic cooperation.

In order to measure the convergence of Western Balkan economies in digital transformation, we use the coefficient of variation ${ }^{7}$ for various proxies of digital transformation using the data for individual economies for the period from 2007 to 2016:

$$
C V_{t}=\frac{\sigma_{t}}{\mu_{t}} * 100, t=2007, \ldots, 2016
$$

where $\sigma_{t}$ stands for the standard deviation, and $\mu_{t}$ for the average of a variable that represents the digital transformation of the economies in the region. The coefficient of variation in our case measures to what extent individual economies differ in digital transformation indicators from the regional average. We calculated the coefficient of variation separately for every year across the economies in the sample for every variable. The decrease of the coefficient of variation through time implies that the variability between the economies in the region is reduced and hence the degree of digital convergence between them has increased. In other

\footnotetext{
6 The calculations are made under the assumption that tourists from all countries on average spend the same amount of money on tourist visits in the analysed countries in the region. However, countries in the region have lower GDP per capita than Western European countries, and hence it is expected that tourists from the region spend less than tourists from Western Europe, which means that we overestimated the total regional earnings from tourism. However, since tourists from the region represent on average 19 percent of all tourist arrivals in the region and tourists from the region together with other tourists from South-eastern and Eastern Europe represent the majority of tourist arrivals in most countries of the region, the bias should be negligible.

7 Coefficient of variation shows the extent of variability in relation to the mean of the variable and it is used when there are large differences in means (over time), which is the case in our dataset.
} 
words, as the coefficient of variation enables us to track to what extent individual economies diverge in percentage terms from the average regional value of a certain digital transformation indicator, the lower value of the indicator thus suggests a more intense digitalisation convergence in the region. Thus, for example, in an extreme case, if the value of a coefficient of variation for the share of internet users in the population in a given year is 0, this would suggest that all Western Balkan economies have the same share of internet users in that year.

Since we are using several different variables for the analysis of digital convergence, in order to come up with a single measure of convergence, we constructed a weighted digital convergence indicator. For parsimony, weights are the same for all individual variables (since we have eight variables, the weight equals 0.125 ). The weighted digital convergence indicator is then calculated as:

$$
D C I_{t}=w_{i} * C V_{i t}, t=2007, \ldots, 2016
$$

where $C V_{i t}$ stands for the coefficient of variation of different digitalisation variables and $w_{i}$ for weight of each variable. Again, the decrease implies that the degree of digital convergence between the economies in the region has increased.

\section{Empirical data and analysis}

\subsection{Data}

For measuring economic cooperation, we use three prominent parts of the balance of payments: foreign trade, FDI and tourism. More precisely, we use data on bilateral merchandise trade flows, foreign direct inflows and tourist arrivals among Western Balkan economies as well as total earnings from tourism. Data on bilateral merchandise trade flows come from the Eurostat COMEXT database, data on foreign direct inflows come from wiiw FDI Database, data on tourist arrivals come from World Tourism Organisation and the Kosovo Agency for Statistics, while data on earnings from tourism come from World Bank World Development Indicators. Data on foreign trade, foreign direct inflows and earnings from tourism are expressed in Euros, while the data for tourism is expressed in the number of tourist arrivals.

Variables representing digital transformation include fixed-telephone subscriptions per 100 inhabitants, mobile-cellular subscriptions per 100 inhabitants, fixed broadband subscriptions per 100 inhabitants, a percentage of the population covered by a mobile-cellular network, internet users (percentage), international internet bandwidth per internet user, estimated proportion of households with a computer and estimated proportion of households with internet access at home. The data for proxies for digital transformation are taken from the WT/ICT database. 
We analysed the following countries: Albania, Bosnia and Herzegovina, Croatia, Kosovo, Montenegro, North Macedonia and Serbia. The period of analysis is 20072017.

\subsection{Economic cooperation of Western Balkan economies}

The values of the harmonised index of economic cooperation suggest an uneven, but rising trend of economic cooperation amongst Western Balkan economies (Figure 1 and Table 1 in the Appendix). The increasing cooperation in the first year was brought to a halt by the global economic downturn in 2008. After a strong decline in 2009, the economic cooperation recovered already in 2010 and continued with a gradual increase until 2017 with a halt in 2013 due to the recession which most of the countries in the region had experienced in the previous year.

As described in the previous section, the contribution of foreign trade, FDI, and tourism to the overall economic cooperation in the region was assessed using the relative weights of these three activities in the index. ${ }^{8}$ The cooperation amongst these economies is dominated by foreign trade, with its share in overall cooperation standing at 73.2 percent in 2017. Compared to trade, cooperation through tourism and especially through FDI in the region is relatively weak, with their share in economic cooperation amounting to 25.0 and 1.8 percent, respectively. Still, the share of tourism has been modestly rising through the years on the expense of trade, but it is a long way before tourism might close the gap with trade. On the other hand, the modest shares of tourism and FDI in the overall economic cooperation reveal a currently untapped potential for further development, which, among other things, could be further enhanced by an increased digital transformation of these economies. Since digital transformation might increase productivity and the growth of GDP (Oliner and Sichel, 2000; Yousefi, 2011) and a higher development might induce increased economic cooperation between countries (Venables, 2003), further digital development of the Western Balkan economies could boost economic cooperation between them, especially in the field of tourism. ${ }^{9}$

\footnotetext{
8 The research subject is of particular importance for encouraging the development of economic cooperation between Western Balkan countries. Although economic cooperation exists in some other areas, such as labour-related migrations, portfolio capital, and factor income flows, it is primarily reflected in the areas of foreign trade, FDI and tourism that contribute most to the creation of demand for domestic products and affect the increase of economic activity, production value and living standards. It is therefore estimated that the research on economic cooperation between Western Balkan countries in these areas is of utmost importance. In addition, it should be added that bilateral data on some other variables such as work-related migrations, portfolio capital, and factor income flows are not available, and we could not include them in the calculation of the harmonized index of economic cooperation. However, it would be reasonable to expect that they too follow the same general trend outlined by the index of economic cooperation.

9 Since ICT provides easier access to information about tourism destinations and products, advancement of ICT coupled with the increase in GDP might lead to an increase in regional tourist arrivals.
} 
Figure 1: Index of economic cooperation for the economies in the region, with contributions of individual economic sectors to the index

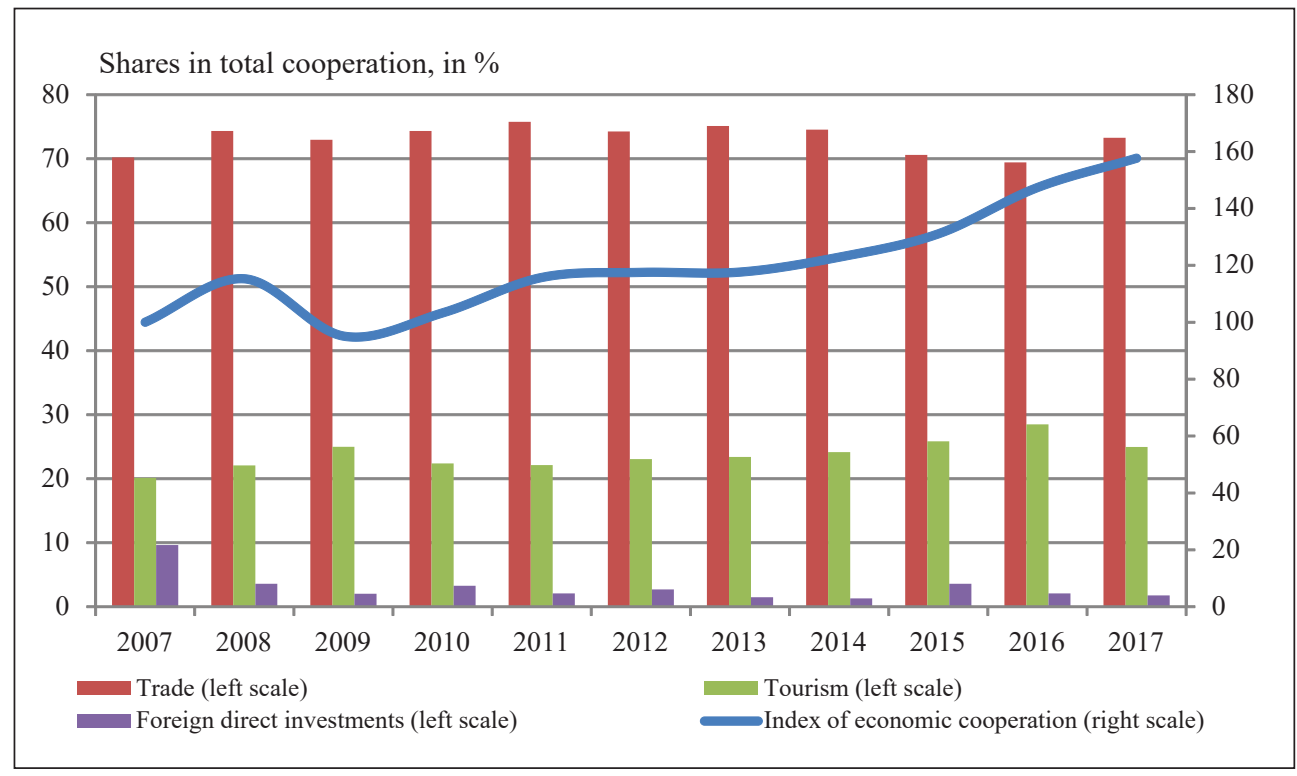

Notes: Index of economic cooperation $-2007=100$; shares in total cooperation - in $\%$.

Source: Authors' calculations

On the level of an economy, the contribution of individual economies is not equal. The largest contribution to economic cooperation among Western Balkan economies comes from Serbia (29.4 percent) and Croatia (24.7 percent). They are followed by Albania (17.7 percent $)^{10}$ and Bosnia and Herzegovina (14.8 percent). North Macedonia, Montenegro and Kosovo have a relatively small contribution to the harmonised index of economic cooperation, mainly due to the smaller size of these economies. Thus, the joint share of these economies in the index of cooperation is 13.4 percent. Even though the contribution of some economies is relatively small to the index, cooperation between neighbouring countries is important, which signals the potential for the spillover effect, including a spillover of the digital transformation process. However, a potential spillover of the digital transformation process between Western Balkan countries might not be the only outcome. Increased digital transformation across the Western Balkan region could also improve the region's attractiveness and increase investments from other parts of Europe and the world.

\footnotetext{
${ }^{10}$ It is interesting to note that a relatively high share of Albania in regional cooperation is mainly due to the estimated revenues from tourism, which mainly come from tourists from Kosovo. Tourists from Kosovo to Albania comprise the largest share of the total number of regional tourists.
} 


\subsection{Digital convergence of Western Balkan economies}

Western Balkan countries, like most other regions in the world, are experiencing a digital transformation measured by the use of fixed-telephones, mobile-cellular telephones, computers and internet. While fixed-telephone subscriptions are dropping, the use of mobile-cellular telephones, computers and internet have increased over time (Figure 2 and Table 2 in the Appendix).

Figure 2: Digital transformation - comparison between regions
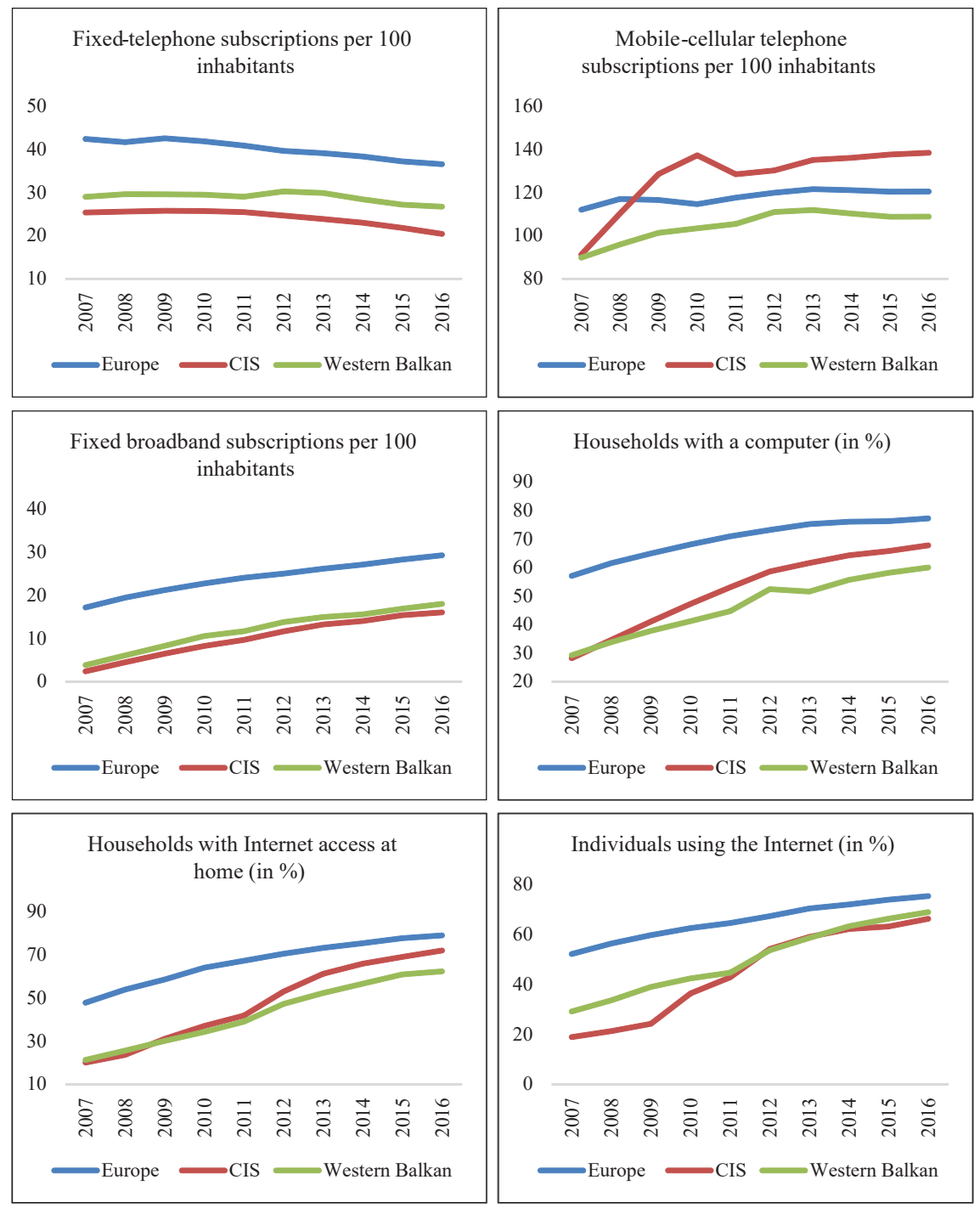
However, when compared with other European ${ }^{11}$ and CIS $^{12}$ countries, the Western Balkan countries are still lagging behind in the use of digital technologies. CIS countries exchanged fixed-telephones with mobile-cellular telephones, while Europe is leading with the possession of computers and the access to and use of the internet. Even though Western Balkan countries are lagging behind, it is important to analyse the degree of convergence in digital transformation between them in order to assess the future prospect for the region.

Our measures of digital convergence between Western Balkan economies, which show to what extent individual economies differ in digital transformation indicators from the regional average, indicate an increase in the convergence of the region in all indicators (Figure 3 and Table 3 in the Appendix). However, there are still pronounced differences between indicators, since the intensity of the digital transformation convergence is different for each digital transformation indicator. The convergence is particularly pronounced in the percentage of the population covered by a mobile-cellular network, the share of internet users, the proportion of households with internet access at home and fixed broadband subscriptions per 100 inhabitants. Although with a somewhat lower intensity, other indicators also confirm the convergence process.

The convergence process has been especially intense in fixed broadband subscriptions per 100 inhabitants. An initial average deviation of individual economies from the regional average of fixed broadband subscriptions per 100 inhabitants amounted to more than 160 percent of the average revealing large differences between Western Balkan economies. As fixed broadband subscriptions in all Western Balkan economies increased substantially over the observed period, by 2016 this deviation decreased to just about 30 percent of the regional average. The convergence among Western Balkan economies is almost complete in the percentage of population covered by a mobile-cellular network, which means that the coverage of a mobile-cellular network is very similar in the region, regardless of the economies' individual level of development.

${ }^{11}$ Europe includes all the EU members, but also Western Balkan and other European countries. Since the data on regions are given in aggregate, it was not possible to extract Western Balkan countries and show data for the rest of European countries. However, since the EU is much larger and more advanced than countries in our sample, the bias should be minimal.

${ }^{12}$ CIS countries include Armenia, Azerbaijan, Belarus, Kazakhstan, Kyrgyzstan, Russian Federation, Tajikistan, Turkmenistan and Uzbekistan. 
Figure 3: Digital transformation convergence - individual indicators, measured by the coefficient of variation
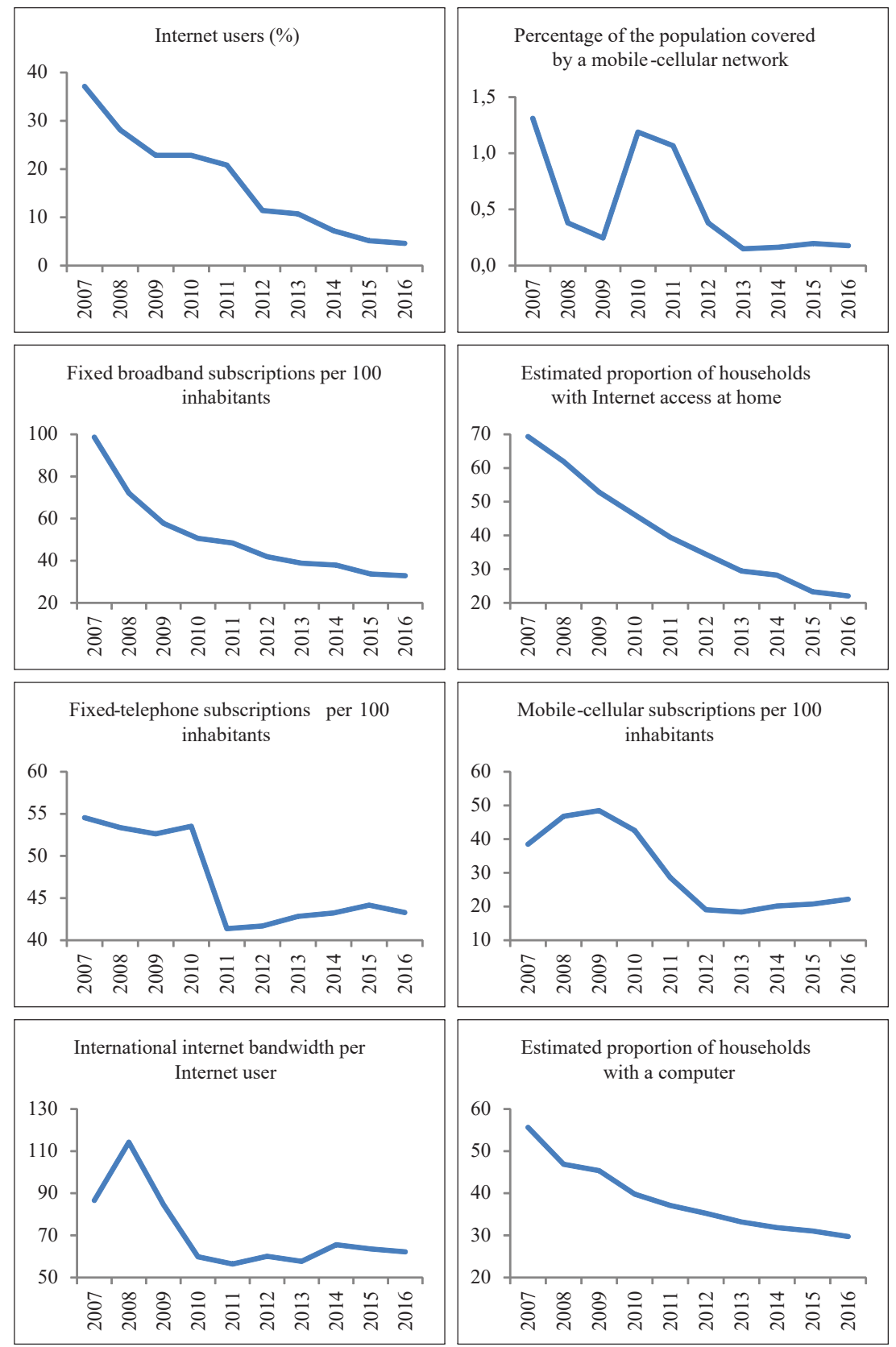

Notes: Scale is in \%; 0 indicates complete convergence; the larger the coefficient of variation, the larger the divergence between Western Balkan economies in a given year.

Source: Authors' calculations 
The decreasing values of the weighted digital transformation indicator over time indicate that Western Balkan economies have indeed experienced an increased digital transformation convergence (Figure 4 and Table 4 in the Appendix).

Figure 4: Digital transformation convergence in Western Balkan, measured by the coefficient of variation

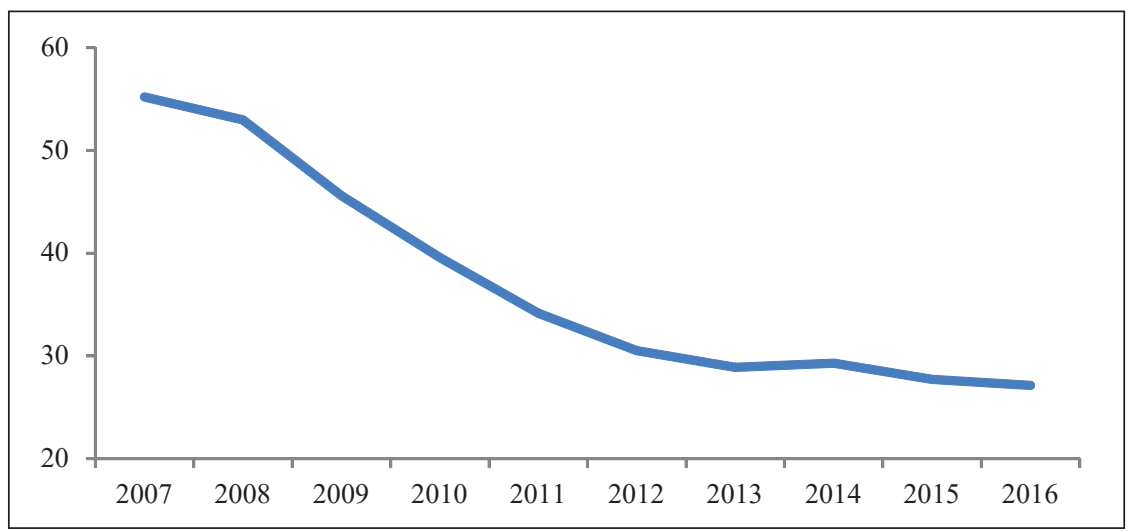

Notes: Scale is in \%; 0 indicates complete convergence; the larger the coefficient of variation, the larger the divergence between Western Balkan economies in a given year.

Source: Authors' calculations

\section{Results and discussion}

The transition period in Western Balkan countries has been marked by the processes of restructuring, privatization, liberalization and economic integration into international goods and capital flows. Despite the existence of many common features in the economic structure of the observed countries, approaches to these processes and an adaptation to new economic and market circumstances still differ significantly amongst the analysed countries. This is partly due to the existing inequalities at the level of economic development, where the dynamics and capacity for implementing structural and institutional reforms of the economies in these countries are different (Buturac, 2013). The integration and globalization processes additionally emphasize the importance of economic cooperation of the Western Balkan countries, all in order to strengthen the international competitiveness of these countries and to achieve stronger economic growth.

In this study we observed trends in economic cooperation between Western Balkan countries, as well as in digital convergence. The results show that economic cooperation between Western Balkan countries increased, with foreign trade 
still being the most important contributor. Since existing research shows that economic cooperation is important for economic growth ( $\mathrm{Ng}$ and Yeats, 2003), the advancement of economic cooperation between Western Balkan countries might draw the region towards higher levels of economic development. Trends are also similar for digital convergence - it increased significantly during the analysed period. We assume that this outcome is mainly the result of the overall technological progress in these economies, as there were no formal initiatives aimed at promoting a harmonized and standardized approach to digital transformation. Thus, as individual technologies are being deployed and used, economies exhibit more convergence both in individual value of coefficients of variation, and in the overall measure of digital transformation convergence.

However, can we claim that digital convergence of the Western Balkan economies that occurred during the analysed period is related to the increase in regional economic cooperation? By comparing Figures 1 and 4 we can state that the digital transformation convergence is positively correlated with economic cooperation. This correlation does not necessary imply causality between these two variables. If digital transformation and economic cooperation occur simultaneously, it does not necessarily mean that one is the cause and the other is the consequence. However, the conclusions drawn are under the assumption that, at least to some extent, there is a causation between the digital transformation and economic cooperation. Thus, placing more emphasis on a harmonized cross-country approach to digital transformation could potentially boost economic cooperation in the future. The benefits of an increased digital transformation and convergence of the region would thereby not be limited just to the increased economic cooperation, but they could also be materialized in terms of an increased economic growth of individual Western Balkan economies.

This research contributes to the literature in several ways. Firstly, we augmented the methodology for calculating the harmonised index of economic cooperation. In this way we were able to analyse economic cooperation between all the economies in the region and discuss trends in cooperation and weight of each component of the index. Secondly, we used a coefficient of variation as a measure of convergence of Western Balkan economies in digital transformation and constructed a weighted digital convergence indicator in order to come up with the single measure of convergence. Hence, we were able to track to what extent individual economies diverge from the average regional value of a certain digital transformation indicator as well as to track the combined convergence of the region. Thirdly, we inferred from the developments of these two measures the possible effects of digitalisation on the economic cooperation of Western Balkan economies. And finally, due to the fact that the contributions of digitalisation are not only of a financial or economic nature, but also have social and political implications, the results obtained in this research can be a good basis for further research not only in economics but also in some other research areas. Broader social implications of the results obtained have particular significance just for Western 
Balkan countries primarily because of their relative geographical proximity, language similarity, existing social-political relationships and common history.

Even though, to the best of our knowledge, there is no other research that tackles together digital transformation and economic cooperation, especially in the Western Balkan region, comparison with similar research corroborates our findings. Broz et al. (2015) show that economic cooperation between Croatia and countries in the Western Balkan region has strongly increased since the beginning of the $21^{\text {st }}$ century and that the cooperation is also dominated by foreign trade. Similarly, Mondekar (2017) shows that South-East Europe is lagging behind Western economies in terms of digital transformation, but with good prospects of catching up.

\section{Conclusion}

In this paper we analysed mutual economic cooperation between the Western Balkan countries, examined their convergence in digital transformation and discussed the relationship between economic cooperation and digitalisation processes. The results show an increase in the economic cooperation between the Western Balkan countries, measured by the harmonised index of economic cooperation, with trade still being the most important component of the index. At the same time, Western Balkan countries exhibited strong digital transformation convergence, with the main driver of convergence being the overall technological progress in these economies. However, when compared with other European and CIS countries, the Western Balkan countries are lagging behind in the use of digital technologies.

Even though digitalisation is not the only driver of economic cooperation, the results of the trends are indicative. If, at least to some extent, there is a causality between the digital transformation and economic cooperation, the observed increase in digital transformation and convergence of Western Balkan countries might have a positive impact on the economic cooperation. This implies that increased digital convergence through the increase of the overall technological progress could strengthen regional economic cooperation and contribute to the economic stability of the region.

Still, there are some limitations of our research. Primarily due to the lack of data, the harmonised index of economic cooperation does not include all economic variables, such as remittances, portfolio capital and factor income flows. Hence, further development and upgrading the research methodology in areas of economic cooperation and digitalisation is needed. Also, other limitations of this research are primarily related to the character of the time period covered by the analysis. The lack of long-time data series disables deeper insights into the nature of relationship between digitalisation process and economic cooperation among countries. In addition, it must be highlighted that the analysis was conducted using the data only at macro level. This study could not involve a micro level analysis that would 
ensure deeper insight into the reasons of strengthening economic cooperation among Western Balkan countries in the circumstances of the process of growing digital convergence among them.

Future research might also tackle the issue of how digitalisation and economic cooperation contribute to the economic growth of Western Balkan countries and especially whether the Western Balkan countries experienced different effects of the digitalisation process on economic growth due to their different economic development stages.

\section{References}

Aruoja, K. (2015) Digital cooperation in the Baltic sea region: A case of networked multi-level governance, Master's thesis, University of Tartu, Estonia.

Arvin, B.M., Pradhan, R.P. (2014) "Broadband penetration and economic growth nexus: evidence from cross-country panel data", Applied Economics, Vol. 46, No. 35, pp. 4360-4369, doi: https://doi.org/10.1080/00036846.2014.957444.

Aubert-Tarby, C., Escobar, O.R., Rayn, T. (2018) "The impact of technological change on employment: The case of press digitisation", Technological Forecasting and Social Change, Vol. 128, pp. 36-45, doi: https://doi.org/10.1016/j.techfore.2017. 10.015 .

Bai, Y. (2019) "The Nuanced Effects of Internet Use on International Trade: An Empirical Analysis of U.S. Trade Data", Available at SSRN: https://ssrn.com/ abstract=3426630, doi: http://dx.doi.org/10.2139/ssrn.3426630.

Barbero, J., Rodriguez-Crespo, E. (2018) "The effect of broadband on European Union trade: A regional spatial approach", Vol. 41, No. 11, pp. 2895-2913, doi: https://doi.org/10.1111/twec.12723.

Barrell, R., Pain, N. (1996) "An Econometric Analysis of U.S. Foreign Direct Investment", Review of Economics and Statistics, Vol. 78, No. 2, pp. 200-207, doi: https://doi.org/10.2307/2109921.

Broz, T., Buturac, G., Tkalec, M. (2015) "To what extent does Croatia really cooperate with SEE countries in the fields of foreign trade, direct investment and tourism?", Economic research-Ekonomska istraživanja, Vol. 28, No. 1, pp. 879-906, doi: https://doi.org/10.1080/1331677X.2015.1092703.

Buturac, G. (2013) „Beyond the Global Recession: Mutual Trade and Economic Convergence“, Ekonomski pregled, Vol. 64, No. 4, pp. 303-326, https://hrcak. srce.hr/106541.

Castaldo, A., Fiorini, A., Maggi, B. (2018) "Measuring (in a time of crisis) the impact of broadband connections on economic growth: an OECD panel analysis", Applied Economics, Vol. 50, No. 8, pp. 838-854, doi: https://doi.org/ 10.1080/00036846.2017.1343448. 
Choi, C. (2003) "Does the Internet Stimulate Inward Foreign Direct Investment?", Journal of Policy Modeling, Vol. 25, No. 4, pp. 319-326. doi: 10.1016/S01618938(02)00202-8.

Choi, C. (2010) "The Effect of the Internet on Service Trade", Economics Letters, Vol. 109, No. 2, pp. 102-104. doi: https://doi.org/10.1016/j.econlet.2010.08.005.

Choi, C., Yi, M.H. (2018) "The Internet, R\&D expenditure and economic growth", Applied Economics Letters, Vol. 25, No. 4, pp. 264-267, doi: https://doi.org/10. 1080/13504851.2017.1316819.

Crandall, R.W., Lehr, W., Litan, R.E. (2007) "The effects of broadband deployment on output and employment: A cross-sectional analysis of US data", Retrieved from: The Brookings Institution website: https://www.brookings.edu/wpcontent/uploads/2016/06/06labor_crandall.pdf.

Czernich, N. et al. (2011) "Broadband infrastructure and economic growth", The Economic Journal, Vol. 121, No. 552, pp. 505-532, doi: https://doi.org/10.1111/ j.1468-0297.2011.02420.x.

De Groen, W.P. et al. (2017) "Impact of digitalisation and the on-demand economy on labour markets and the consequences for employment and industrial relations", Final Study, CEPS Special Report, August 2017. Retrieved from: https://www.eesc.europa.eu/resources/docs/qe-02-17-763-en-n.pdf.

Dedrick, J., Kraemer, K.L., Shih, E. (2013) "Information technology and productivity in developed and developing countries", Journal of Management Information Systems, Vol 30, No. 1, pp. 97-122, doi: https://doi.org/10.2753/MIS07421222300103.

Degryse, C. (2016) "Digitalisation of the economy and its impact on labour markets", ETUI Research Paper-Working Paper, No. 2016.02, ETUI: Brussels, doi: https://doi.org/10.2139/ssrn.2730550.

Duttaray, M., Dutt, A.K., Mukhopadhyay, K. (2008) "Foreign direct investment and economic growth in less developed countries: an empirical study of causality and mechanisms", Applied Economics, Vol. 40, pp. 1927-1939, doi: https://doi. org/10.1080/00036840600949231.

Freund, C., Weinhold, D. (2004) "The Effect of the Interneton International Trade", Journal of International Economics, Vol. 62, No. 1, pp. 171-189. doi: https:// doi.org/10.1016/S0022-1996(03)00059-X.

Ghosh, S. (2017) "Broadband penetration and economic growth: Do policies matter?", Telematics and Informatics, Vol. 34, No. 5, pp. 676-693, doi: https:// doi.org/10.1016/j.tele.2016.12.007.

Gnangnon, S.K., Iyer, H. (2018) "Does bridging the Internet Access Divide contribute to enhancing countries' integration into the global trade in services markets?", Telecommunications Policy, Vol. 42, No. 1, pp. 61-77, doi: https:// doi.org/10.1016/j.telpol.2017.08.004. 
Gómez-Plana, A.G., Latorre, M.C. (2019) "Digitalization, Multinationals and Employment: An Empirical Analysis of Their Causal Relationships", Journal of Economics and Statistics, Vol. 239, No. 3, pp. 399-439, doi: https://doi. org/10.1515/jbnst-2017-0153.

Gries, T., Redlin, M. (2012) "Trade Openness and Economic Growth: A Panel Causality Analysis", Working Papers CIE, No. 52, Paderborn: Paderborn University, CIE Center for International Economics, http:/groups.unipaderborn.de/wp-wiwi/RePEc/pdf/ciepap/WP52.pdf.

Grimes, A., Ren, A., Stevens, P. (2012) "The need for speed: impacts of internet connectivity on firm productivity", Journal of Productivity Analysis, Vol. 37, No. 2, pp. 187-201, doi: http://dx.doi.org/10.2139/ssrn.1604247.

Gruber, H. et al. (2014) "Broadband access in the EU: An assessment of future economic benefits", Telecommunications Policy, Vol. 38, No. 11, pp. 10461058, doi: https://doi.org/10.1016/j.telpol.2014.06.007.

Gruber, H., Koutroumpis, P. (2011) "Mobile telecommunications and the impact on economic development", Economic Policy, Vol. 26, No. 67, pp. 387-426, doi: https://doi.org/10.1111/j.1468-0327.2011.00266.x.

Haftu, G.G. (2019) "Information communications technology and economic growth in Sub-Saharan Africa: A panel data approach", Telecommunications Policy, Vol. 43, No. 1, pp. 88-99, doi: https://doi.org/10.1016/j.telpol.2018.03.010.

Haller, S.A., Lyons, S. (2019) "Effects of broadband availability on total factor productivity in service sector firms: Evidence from Ireland", Telecommunications Policy, Vol. 43, No. 1, pp. 11-22, doi: https://doi.org/10.1016/j.telpol.2018.09.005.

Hsiao, F.S.T., Hsiao, M-C.W. (2006) "FDI, exports, and GDP in East and Southeast Asia - Panel data versus time-series causality analyses", Journal of Asian Economics, Vol. 17, No. 6, pp. 1082-1106, doi: https://doi.org/10.1016/j. asieco.2006.09.011.

Kabaklarli, E., Atasoy, B.S. (2019) "Broadband infrastructure and economic growth: a panel data approach for selected countries", Vol. 4, No. 1, pp. 105-114.

Katz, R.L. et al. (2010) "The impact of broadband on jobs and the German economy", Intereconomics, Vol. 45, No. 1, pp. 26-34, doi: https://doi. org/10.1007/s10272-010-0322-y.

Katz, R.L., Koutroumpis, P. (2013) "Measuring digitization: A growth and welfare multiplier”, Technovation, Vol. 33, No. 10, pp. 314-319, doi: https://doi. org/10.1016/j.technovation.2013.06.004.

Kolko, J. (2012) "Broadband and local growth", Journal of Urban Economics, Vol. 71, No. 1, pp. 100-113, doi: http://dx.doi.org/10.1016/j.jue.2011.07.004.

Kotarba, M. (2017) "Measuring Digitalization - Key Metrics", Foundations of Management, Vol. 9, No. 1, pp. 132-138, https://content.sciendo.com/abstract/ journals/fman/9/1/article-p123.xml. 
Koutroumpis, P. (2009) "The economic impact of broadband on growth: A simultaneous approach", Telecommunications policy, Vol. 33, No. 9, pp. 471485, doi: https://doi.org/10.1016/j.telpol.2009.07.004.

Lee, S. (2016) "Geography of cross-border portfolio investments and ICT diffusion", International Review of Economics and Finance, Vol. 45, pp. 540552, doi: 10.1016/j.iref.2016.07.01.

Lee, S.H., Levendis, J., Gutiérrez, L. (2012) "Telecommunications and economic growth: an empirical analysis of sub-Saharan Africa", Applied Economics, Vol. 44, No. 4, pp. 461-469, doi: http://dx.doi.org/10.1080/00036846.2010.508730.

Lehr, W.H. et al. (2006) "Measuring Broadband's Economic Impact”, ESD Working Papers, ESD-WP-2006-02, Massachusetts Institute of Technology. http://hdl. handle.net/1721.1/102779.

Lin F. (2015) "Estimating the effect of the Internet on international trade", Journal of International Trade and Economic Development, Vol. 24, No. 3, pp. 409428, doi: 10.1080/09638199.2014.881906.

Liu, X, Burridge, P., Sinclair, P.J.N. (2002) "Relationships between economic growth, foreign direct investment and trade: evidence from China", Applied Economics, Vol. 34, No. 11, pp. 1433-1440, doi: https://doi.org/10.1080/ 00036840110100835.

Majumdar, S. K., Carare, O., Changy, H. (2009) "Broadband adoption and firm productivity: evaluating the benefits of general purpose technology", Industrial and Corporate Change, Vol. 19, No. 3, pp. 641-674, doi: https://doi.org/10.1093/ icc/dtp042.

Minges, M. (2015) "Exploring the relationship between broadband and economic growth", World Development Report 2016: Digital Dividends, World Bank.

Mondekar, D. (2017) The digital economy in Southeast Europe: Opportunities and challenges, Zagreb: Friedrich-Ebert-Stiftung, Regional Office for Croatia and Slovenia, Zagreb.

Ng, T.H., Lye, C.T., Lim, Y.S. (2013) "Broadband penetration and economic growth in ASEAN countries: a generalized method of moments approach", Applied Economics Letters, Vol. 20, No. 9, pp. 857-862, doi: https://doi.org/10.1080/13 504851.2012 .754538 .

Ng, F., Yeats, A. (2003) "Major Trade Trends in East Asia: What are their Implications for Regional Cooperation and Growth?", World Bank Policy Research Working Paper, No. 3084, doi: https://doi.org/10.1596/1813-9450-3084.

Oliner, S.D., Sichel, D.E. (2000) "The Resurgence of Growth in the Late 1990s: Is Information Technology the Story?", Journal of Economic Perspectives, Vol. 14, No. 4, pp. 3-22, doi: https://doi.org/10.1257/jep.14.4.3.

Piatkowski, M. (2006) "Can information and communication technologies make a difference in the development of transition economies?", Information Technologies \& International Development, Vol. 3, No.1, pp. 39-53. 
Rodríguez-Crespo, E., Martínez-Zarzoso, I. (2019) "The effect of ICT on trade: Does product complexity matter?", Telematics and Informatics, Vol. 41, pp. 182-196, doi: https://doi.org/10.1016/j.tele.2019.05.001.

Roller, L.H., Waverman, L. (2001) "Telecommunications infrastructure and economic development: A simultaneous approach", American economic review, Vol. 91, No. 4, pp. 909-923, doi: https://doi.org/10.1257/aer.91.4.909.

Venables, A.J. (2003) "Winners and Losers from Regional Integration Agreements", Economic Journal, Vol. 113, No. 490, pp. 747-761, doi: https://doi.org/10.1111/ 1468-0297.t01-1-00155.

Yi, M.H., Choi, C. (2005) "The effect of the Internet on inflation: Panel data evidence" Journal of Policy Modeling, Vol. 27, No. 7, pp. 885-889, doi: https:// doi.org/10.1016/j.jpolmod.2005.06.008.

Yousefi, A. (2011) "The impact of information and communication technology on economic growth: evidence from developed and developing countries", Economics of Innovation and New Technology, Vol. 20, No. 6, pp. 581-596, doi: https://doi.org/10.1080/10438599.2010.544470.

Zoroja, J. (2011) "Internet, e-commerce and e-government: measuring the gap between European developed and post-communist countries", Interdisciplinary Description of Complex Systems: INDECS, Vol. 9, No. 2, pp. 119-133. 


\title{
Digitalna transformacija i gospodarska suradnja: slučaj zemalja zapadnog Balkana
}

\author{
Tanja Broz ${ }^{1}$, Goran Buturac ${ }^{2}$, Miloš Parežanin ${ }^{3}$
}

\begin{abstract}
Sažetak
Digitalna transformacija utječe na mnoge aspekte svjetske ekonomije. Ona podiže gospodarski rast, utječe na inozemna izravna ulaganja te povećava trgovinsku razmjenu. Stoga je cilj ovoga rada analizirati digitalnu transformaciju i gospodarsku suradnju između zemalja zapadnog Balkana. Metodologija istraživanja zasniva se na dva pokazatelja: harmoniziranom indeksu gospodarske suradnje između zemalja zapadnog Balkana i pokazatelju konvergencije digitalne transformacije. Rezultati ukazuju na rastući trend gospodarske suradnje između zemalja zapadnog Balkana, s tim da u suradnji dominira vanjska trgovina. Iako su zemlje zapadnog Balkana iskusile povećanu konvergenciju u digitalnoj transformaciji, one i dalje zaostaju za EU u upotrebi digitalnih tehnologija. Stoga, stavljanje naglaska na digitalnu transformaciju bi potencijalno moglo povećati regionalni BDP i time gospodarsku suradnju između zemalja zapadnog Balkana.
\end{abstract}

Ključne riječi: digitalna transformacija, regionalna gospodarska suradnja, zemlje zapadnog Balkana

JEL klasifikacija: F15, F21, O33

1 Viša znanstvena suradnica, Ekonomski institut, Zagreb, Trg J. F. Kennedyja 7, 10000 Zagreb, Hrvatska.Tel.: +38512362 233.E-mail:tbroz@eizg.hr.

${ }^{2}$ Znanstveni savjetnik u trajnom zvanju, Ekonomski institut, Zagreb, Trg J. F. Kennedyja 7, 10000 Zagreb, Hrvatska.Tel.: +38512362 297.E-mail: gbuturac@eizg.hr.

${ }^{3}$ Asistent, Sveučilište u Beogradu, Fakultet organizacijskih znanosti, Jove Ilića 154, Beograd, Srbija.Tel.:+381113950 919.E-mail:milos.parezanin@fon.bg.ac.rs. 


\section{Appendices}

Table 1: Index of economic cooperation for the Western Balkan economies and shares of individual economic sectors in the index

\begin{tabular}{|c|c|c|c|c|}
\hline Year & $\begin{array}{c}\text { Index of economic } \\
\text { cooperation } \\
(2007=100)\end{array}$ & $\begin{array}{c}\text { Share of } \\
\text { international } \\
\text { trade in total } \\
\text { cooperation } \\
\text { (in \%) }\end{array}$ & $\begin{array}{c}\text { Share of tourism in } \\
\text { total cooperation } \\
\text { (in \%) }\end{array}$ & $\begin{array}{c}\text { Share of FDI in } \\
\text { total cooperation } \\
\text { (in \%) }\end{array}$ \\
\hline 2007 & 100.0 & 70.2 & 20.1 & 9.6 \\
\hline 2008 & 115.3 & 74.3 & 22.1 & 3.6 \\
\hline 2009 & 95.1 & 73.0 & 25.0 & 2.0 \\
\hline 2010 & 103.3 & 74.3 & 22.4 & 3.3 \\
\hline 2011 & 115.7 & 75.8 & 22.1 & 2.1 \\
\hline 2012 & 117.5 & 74.2 & 23.1 & 2.7 \\
\hline 2013 & 117.6 & 75.1 & 23.4 & 1.5 \\
\hline 2014 & 122.9 & 74.5 & 24.1 & 1.3 \\
\hline 2015 & 131.1 & 70.6 & 25.8 & 3.6 \\
\hline 2016 & 147.4 & 69.4 & 28.5 & 2.1 \\
\hline 2017 & 157.7 & 73.3 & 25.0 & 1.8 \\
\hline
\end{tabular}

Source: Authors' calculations 
Tanja Broz, Goran Buturac, Miloš Parežanin • Digital transformation and economic...

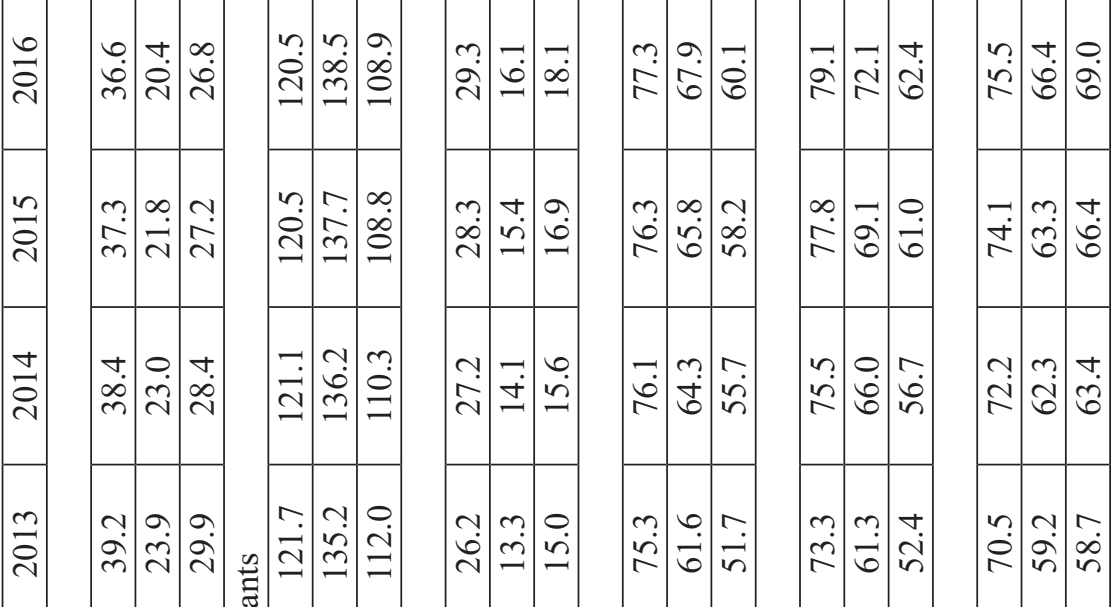

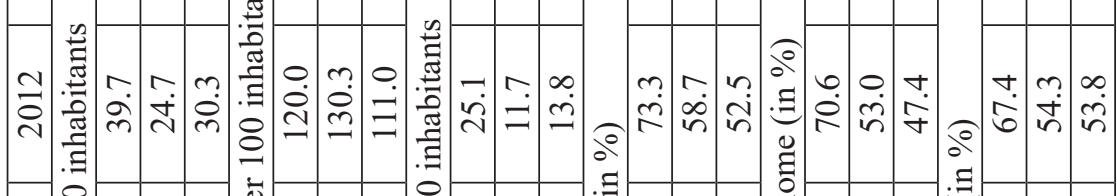

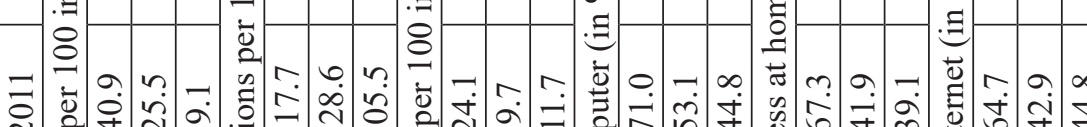

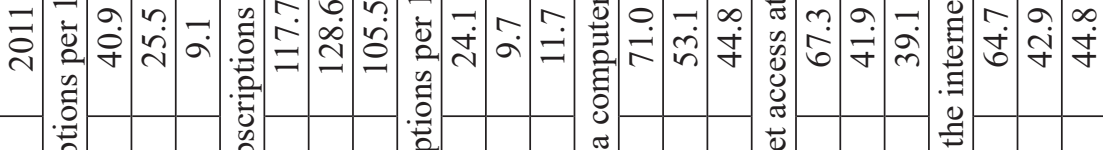

○

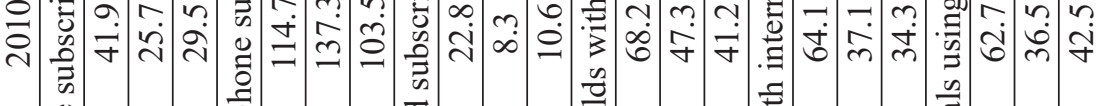

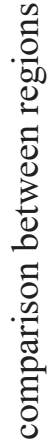

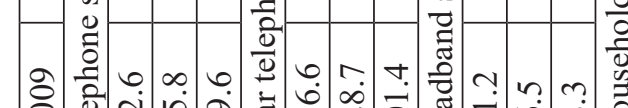

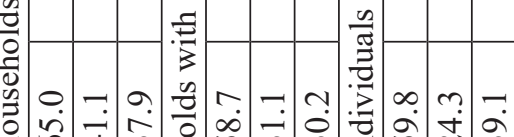

$=$

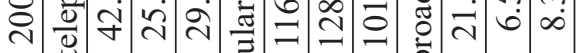

紊

每

$+7$

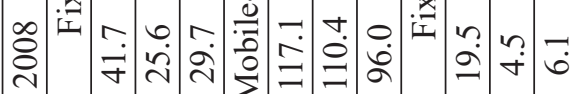

王守向

i min

ヘิ)

こ̇

r.:

2.

$m$ m.

苞

$\ddot{\sim}$

$\frac{0}{\frac{\pi}{0}}$
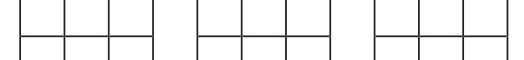

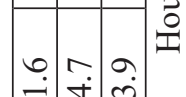

-்

n

ஜำ

$$
\text { . }
$$

$\frac{\sqrt[3]{0}}{0}$
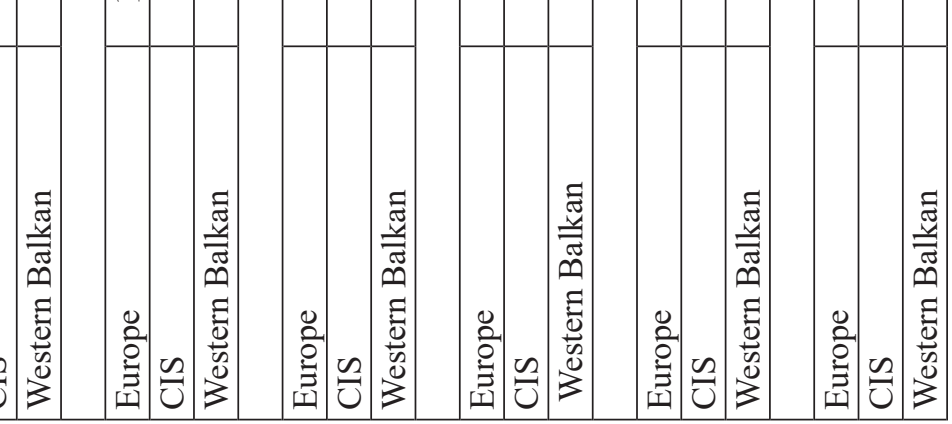

0
0
0
0
0
0
0 
0
0
0
0
0
0
0
0
0
0
0
0
0
0
0
0

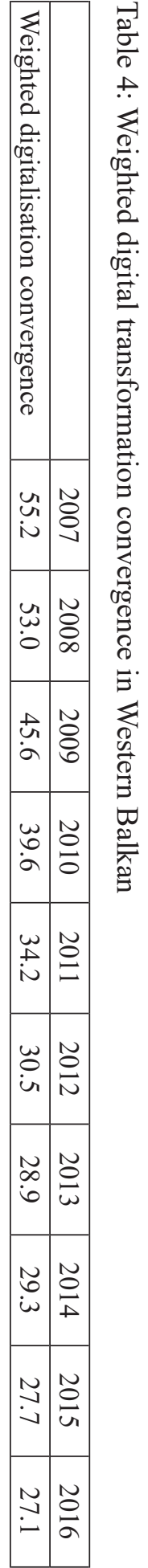

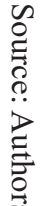

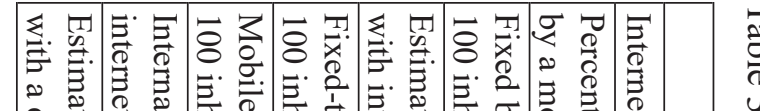

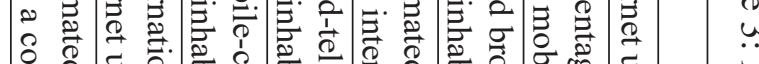

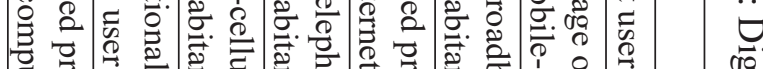

焉

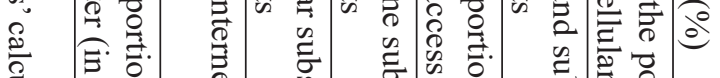

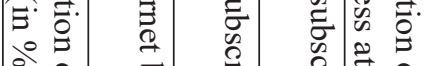

0
0
0
0
0
0
0
$\frac{0}{0}$
$\frac{0}{2}$

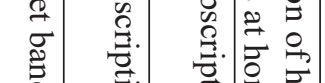

퓽

(2)

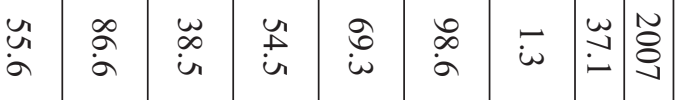

$\stackrel{2}{\circ}$.

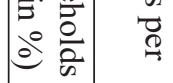

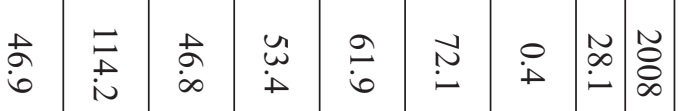

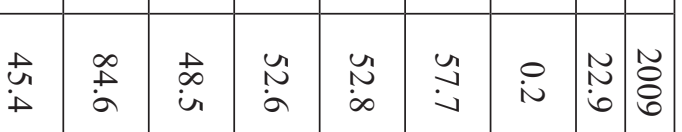

实

:

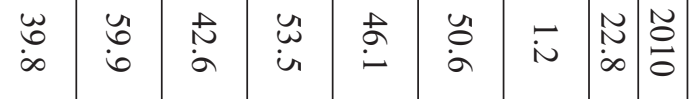

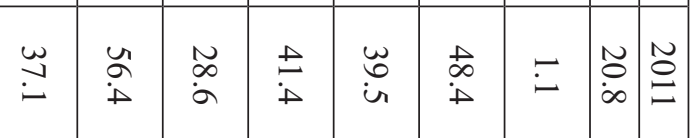

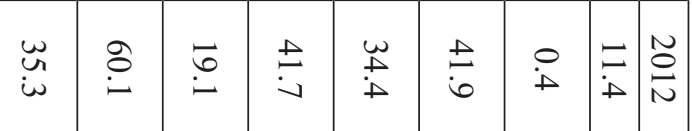

\begin{tabular}{|c|c|c|c|c|c|c|c|c|}
\hline$\underset{\omega}{\omega}$ & $y$ & $\vec{\infty}$ & N & $\widetilde{\sigma}$ & $\underset{\infty}{\omega}$ &. & $\overrightarrow{0}$ & $\tilde{O}$ \\
\hline i & $\forall$ & 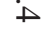 & $\infty$ & $\therefore$ & $\infty$ & $r$ & $\checkmark$ & $\vec{\omega}$ \\
\hline
\end{tabular}

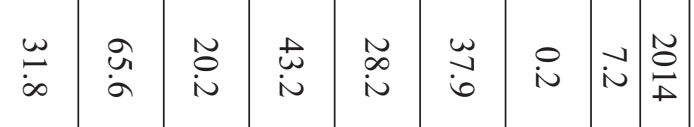

\begin{tabular}{|c|c|c|c|c|c|c|c|c|}
\hline$\frac{\omega}{0}$ & 心) & $\stackrel{N}{0}$ & $\stackrel{t}{t}$ & $\underset{\omega}{\sim}$ & $\omega$ & $\stackrel{o}{i}$ & $\ddot{\prime \prime}$ & $\stackrel{N}{\circ}$ \\
\hline & & & & & & & & \\
\hline$\approx$ & ิㅗ & $\stackrel{N}{N}$ & $\stackrel{\vec{\omega}}{*}$ & $\stackrel{N}{N}$ & $\stackrel{\omega}{N}$ & 0 & $\stackrel{\Delta}{ }$ & $\stackrel{\circ}{\circ}$ \\
\hline- & $\dot{\sim}$ & iN & i & 0 & 6 & i & $a$ & $a$ \\
\hline
\end{tabular}

